\title{
Case Report: COVID-19 with cytokine storm in a 16-year-old patient: if heart failures comes think about levosimendan
}

\section{[version 1; peer review: 2 approved with reservations]}

\author{
Veronica Rodriguez-Garcia1,2, Jose Luis Guerrero Orriach (Di)1-3, \\ Daniel Ariza Villanueva2, Jose Manuel Garcia Pinilla4, Ainhoa Robles Mezcua4, \\ Manuel Rubio Navarro1,2, Jose Cruz Mañas'1,2 \\ ${ }^{1}$ ANESTHESIA-CARDIOLOGY DEPARTMENT, Malaga, Spain \\ ${ }^{2}$ Department of Anaesthesia, Virgen de la Victoria University Hospital, Malaga, Spain \\ ${ }^{3}$ Department of Pharmacology and Pediatrics, School of Medicine, University of Malaga, Malaga, Spain \\ ${ }^{4}$ Department of Cardiology, Virgen de la Victoria University Hospital, Malaga, Spain
}

V1 First published: 26 Mar 2021, 10:244

https://doi.org/10.12688/f1000research.50782.1

Latest published: 07 Feb 2023, 10:244

https://doi.org/10.12688/f1000research.50782.2

\section{Abstract}

Introduction: Our case is unique because the differential diagnosis was a challenge. At first, the patient presented with septic shock and multi-organ failure in the context of a suspected lymphoproliferative syndrome. Once the lymphoproliferative process had been ruled out, hemophagocytic syndrome due to COVID-19 infection was suspected, so he is probably one of the few patients with such an exhaustive study that could contribute to our understanding of COVID-19. We followed therapeutic guidelines that differ from the usual, using adrenalin and levosimendan. Corticosteroids helped to modulate the cytokine storm.

Case report: A 16-year-old adolescent was admitted to the intensive care unit with fever, diarrhea, multiorgan failure and septic shock. He was IgG positive for COVID-19 and IgM negative. Thoraco-abdominal computed tomography demonstrated multiple para-aortic and peripancreatic lymphadenopathy and acute respiratory distress syndrome. The first suspected diagnosis was a lymphoproliferative syndrome and bacterial infection. The second possibility was a hemophagocytic syndrome in a patient recovering from COVID-19. He was treated with broad spectrum antibiotics because the differential diagnosis was difficult, and we removed them when the microbiological screening was negative. During the course of the disease he presented with severe biventricular dysfunction, probably due to the cytokine storm, so we used inotropic drugs (adrenaline, levosimendan). Infection with Salmonella species group B was diagnosed later, when the patient was in the Internal Medicine ward, although he was asymptomatic.

Conclusion: The severity of COVID-19 infection ranges from mild to

\section{Open Peer Review}

Approval Status ?

12

version 2

(revision)

$07 \mathrm{Feb} 2023$

version 1

26 Mar 2021

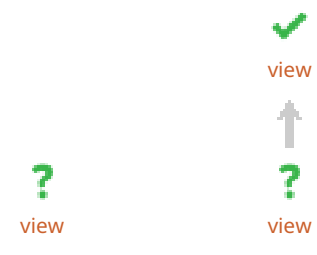

1. Cecilia Bonazzetti (D), Luigi Sacco University Hospital, Milan, Italy

2. Hrvoje Jakovac ID, University of Rijeka, Rijeka, Croatia

Any reports and responses or comments on the article can be found at the end of the article. 
severe, causing serious disease in some people. Although the pathophysiology is not well known, it seems that in some cases an immune storm is triggered, and it is related to more serious and prolonged disease. In our case, heart failure was important, because it could have worsened the prognosis. Fortunately, the response to levosimendan and corticosteroids was adequate and he recovered favorably until discharge.

\section{Keywords}

COVID-19, myocarditis, multiorganic failure, levosimendan, case report.

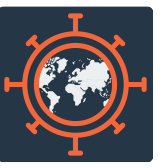

This article is included in the Emerging Diseases and Outbreaks gateway.

\section{Corresponding author: Veronica Rodriguez-Garcia (veronicardguez@gmail.com)}

Author roles: Rodriguez-Garcia V: Investigation, Methodology, Supervision, Validation, Writing - Original Draft Preparation; Guerrero Orriach JL: Investigation, Methodology; Ariza Villanueva D: Investigation, Methodology; Garcia Pinilla JM: Investigation; Robles Mezcua A: Conceptualization; Rubio Navarro M: Methodology; Cruz Mañas J: Writing - Original Draft Preparation Competing interests: No competing interests were disclosed.

Grant information: The author(s) declared that no grants were involved in supporting this work.

Copyright: @ 2021 Rodriguez-Garcia V et al. This is an open access article distributed under the terms of the Creative Commons Attribution License, which permits unrestricted use, distribution, and reproduction in any medium, provided the original work is properly cited.

How to cite this article: Rodriguez-Garcia V, Guerrero Orriach JL, Ariza Villanueva D et al. Case Report: COVID-19 with cytokine storm in a 16-year-old patient: if heart failures comes think about levosimendan [version 1; peer review: 2 approved with reservations] F1000Research 2021, 10:244 https://doi.org/10.12688/f1000research.50782.1

First published: 26 Mar 2021, 10:244 https://doi.org/10.12688/f1000research.50782.1 


\section{Introduction}

The first cases of acute respiratory syndrome caused by COVID-19 were diagnosed in Hubei, China, in December 2019. The high rate of infectivity of the microorganism has triggered a pandemic. Symptoms include dry cough, headache, dyspnea, diarrhea, or fever. However, COVID-19 may also cause respiratory failure, kidney failure, cardiac injury, and central nervous system damage. Patients with comorbidities such as hypertension, obesity, or diabetes are at a higher risk of developing severe symptoms ${ }^{1}$.

Although the pathophysiology of the virus remains unknown, several studies have associated COVID-19 with a cytokine storm quite similar to that occurring in hemophagocytic syndrome (macrophage activation syndrome). This syndrome is characterized by elevated levels of interleukins (IL-1b, IL-6, IL-10, IL-12), interferon (alpha, gamma), and tumor necrosis factor (TNF-alpha); hypertriglyceridemia; hyperferritinemia; hemophagocytosis in the bone marrow, cerebrospinal fluid, or lymph nodes; and manifests in the form of fever, hepatosplenomegaly, hemorrhagic diathesis, cutaneous rash and alterations of consciousness ${ }^{2}$.

The myocardial depressant effect of cytokines, an oxygen deficit generated by a prothrombotic state and coronary vasospasms could cause cardiac injury and dysfunction in other organs.

IL-6, cardiac troponins (cTnI/T), and the amino-terminal fraction of the cerebral natriuretic propeptide (NT-proBNP) have been documented to be elevated in patients with cardiac failure secondary to COVID- $19^{3}$.

Viral myocarditis is a widely described condition, with symptoms such as heart failure. It usually develops within one to three weeks of COVID-19 infection. Potential COVID-19 myocarditis therapies are based on inotropic drugs and extracorporeal life support ${ }^{4}$. Levosimendan should be valued as a useful therapy in this type of patients due to its inotropic effects maintained over time and its associated organ protective effects ${ }^{5}$, which are essential for cardiocirculatory support in cases such as the one reported in this paper.

Our case is unique because the differential diagnosis was quite difficult and interesting. First, it seemed the patient had septic shock and a lymphoproliferative syndrome. Then we thought about hemophagocytic syndrome as well, so he is probably one of the few patients with such an exhaustive study at the immune and hematological level, which could help to understand COVID-19.

Besides that, we follow therapeutic guidelines that differ from the usual, using levosimendan as an inotropic agent ${ }^{6}$ with $^{\circ}$ very good results and corticosteroids ${ }^{7}$ without tocilizumab ${ }^{8}$ due to suspected hemophagocytic syndrome, which helped to modulate the autoimmune response due to the cytokine storm without the need for more immunosuppression with monoclonal antibodies.

\section{Case presentation}

Patient information

The patient was a 16-year-old Spanish adolescent, Caucasian, with no allergies, with extrinsic asthma treated with corticosteroids and aerosols occasionally. He has no relevant past interventions and no medical, family or psychosocial history (including genetic) of interest. He presented with general discomfort, asthenia and fever $\left(38^{\circ} \mathrm{C}\right)$ for three days and was treated with paracetamol $1 \mathrm{~g} / 8$ hours and azithromycin $500 \mathrm{mg} / 24$ hours for three days at home. After seven days, he came to the emergency department with persistence of symptoms, shortness of breath, arthromyalgia and diarrhea.

\section{Clinical findings}

Physical examination revealed a bad general condition. Blood pressure was 70/30 $\mathrm{mmHg}$, heart rate was $110 \mathrm{bpm}$, respiratory rate was $18 \mathrm{bpm}$, and axillary temperature was $38.5^{\circ} \mathrm{C}$. Lung auscultation found bibasilar crackles and heart auscultation found no murmurs. He had hepatosplenomegaly, oliguria, no edemas, no cutaneous rash and no arthritis. He had diuresis of $170 \mathrm{ml}$ in 12 hours. The results of laboratory testing were: white blood cell count $10200^{9} / \mathrm{L}$, with $84.2 \%$ neutrophils, red blood cell count $4.2^{12} / \mathrm{L}$, hemoglobin $12.5 \mathrm{~g} / \mathrm{L}$, platelet count $104000^{9} / \mathrm{L}$, serum C-reactive protein level $269.4 \mathrm{mg} / \mathrm{L}$, alanine aminotransferase level $81 \mathrm{U} / \mathrm{L}$, aspartate aminotransferase level $71 \mathrm{U} / \mathrm{L}$, total bilirubin level $3.30 \mathrm{mg} / \mathrm{dL}$, direct bilirubin level $2.73 \mathrm{mg} / \mathrm{dL}$, cardiac troponin I $1135 \mathrm{pg} / \mathrm{ml}$, blood urea nitrogen $48 \mathrm{mmol} / \mathrm{L}$, creatinine $2.72 \mu \mathrm{mol} / \mathrm{L}$, erythrocyte sedimentation rate of $12 \mathrm{~mm} / \mathrm{h}$, procalcitonin $1.96 \mathrm{ng} / \mathrm{ml}$, arterial $\mathrm{pH}$ of $7.32, \mathrm{pCO}_{2}$ of $50.2 \mathrm{mmHg}, \mathrm{pO}_{2}$ of $68 \mathrm{mmHg}, \mathrm{HCO}_{3} 23 \mathrm{mmol} / \mathrm{L}, \mathrm{SO}_{2} 94 \%$, lactic acid $2.2 \mathrm{mmol} / \mathrm{L}$, ferritin $655.4 \mathrm{ng} / \mathrm{mL}$, triglycerides $161 \mathrm{mg} / \mathrm{dL}$, uric acid $11.3 \mathrm{mg} / \mathrm{dL}$, prothrombin activity $64.7 \%$, international normalized ratio 1.28 , activated partial thromboplastin time (aPTT) 28.9 seconds, aPTT ratio 1.16 and D-dimer $7.500 \mathrm{ng} / \mathrm{ml}$. The evolution of laboratory parameters during admission to the Intensive Care Unit (ICU) is shown in Table 1. 
Table 1. Sepsis parameters.

\begin{tabular}{|c|c|c|c|c|}
\hline & $\begin{array}{l}\text { ICU } \\
\text { admission }\end{array}$ & $\begin{array}{l}\text { Three days after } \\
\text { admission }\end{array}$ & $\begin{array}{l}\text { Six days after } \\
\text { admission }\end{array}$ & $\begin{array}{l}\text { ICU } \\
\text { discharge }\end{array}$ \\
\hline Leukocytes & $10600 \mu \mathrm{L}^{-1}$ & $31280 \mu \mathrm{L}^{-1}$ & $25320 \mu \mathrm{L}^{-1}$ & $12600 \mu \mathrm{L}^{-1}$ \\
\hline Neutrophils & $8720 \mu \mathrm{L}^{-1}$ & $27730 \mu \mathrm{L}^{-1}$ & $21190 \mu \mathrm{L}^{-1}$ & $9348 \mu \mathrm{L}^{-1}$ \\
\hline CRP & $252.3 \mathrm{mg} . \mathrm{I}^{-1}$ & $92.9 \mathrm{mg.l}^{-1}$ & $46{\mathrm{mg} . \mathrm{I}^{-1}}^{-1}$ & $12.2{\mathrm{mg} . \mathrm{I}^{-1}}^{-1}$ \\
\hline Procalcitonine & $1.96 \mathrm{ng}^{-\mathrm{I}^{-1}}$ & $23.22 \mathrm{ng} . \mathrm{I}^{-1}$ & $0.27{\mathrm{ng} . \mathrm{I}^{-1}}^{-1}$ & $0.1 \mathrm{ng} . \mathrm{I}^{-1}$ \\
\hline Lactic acid & $2.2 \mathrm{mmol} . \mathrm{I}^{-1}$ & $2.7 \mathrm{mmol} . \mathrm{I}^{-1}$ & $1.1 \mathrm{mmol} . \mathrm{I}^{-1}$ & $1.2 \mathrm{mmol}^{-\mathrm{I}^{-1}}$ \\
\hline Hemoglobin & $13.2{\mathrm{~g} . \mathrm{dl}^{-1}}^{-1}$ & $9.4 \mathrm{~g} \cdot \mathrm{dl}^{-1}$ & $10.5 \mathrm{~g} \cdot \mathrm{dl}^{-1}$ & $10.2 \mathrm{~g} \cdot \mathrm{dl}^{-1}$ \\
\hline Platelets & $105000 \mu \mathrm{L}^{-1}$ & $248000 \mu \mathrm{L}^{-1}$ & $584000 \mu \mathrm{L}^{-1}$ & $874000 \mu \mathrm{L}^{-1}$ \\
\hline Ferritin & $655.4 \mathrm{ng} \cdot \mathrm{ml}^{-1}$ & $402 \mathrm{ng} \cdot \mathrm{ml}^{-1}$ & $497 \mathrm{ng} \cdot \mathrm{ml}^{-1}$ & $521.6 \mathrm{ng} \cdot \mathrm{ml}^{-1}$ \\
\hline D-dimer & $7172 \mathrm{ng} \cdot \mathrm{ml}^{-1}$ & $4103 \mathrm{ng} \cdot \mathrm{ml}^{-1}$ & $2724 \mathrm{ng} \cdot \mathrm{ml}^{-1}$ & $833 \mathrm{ng} \cdot \mathrm{ml}^{-1}$ \\
\hline Fibrinogen & $546.8 \mathrm{mg} \mathrm{dl}^{-1}$ & $316.8 \mathrm{mg} \cdot \mathrm{dl}^{-1}$ & $323.7 \mathrm{mg} \cdot \mathrm{dl}^{-1}$ & $286.7 \mathrm{mg} \cdot \mathrm{dl}^{-1}$ \\
\hline LDH & $188{\mathrm{U} . \mathrm{I}^{-1}}^{-1}$ & $359 \mathrm{U.I}^{-1}$ & 248 U. $\mathrm{I}^{-1}$ & $136 \mathrm{U.I}^{-1}$ \\
\hline CK & $22{\mathrm{U} . \mathrm{I}^{-1}}^{-1}$ & 49 U. $^{-1}$ & $34 \cup . I^{-1}$ & $15 \cup . I^{-1}$ \\
\hline Troponin I & 1135 ng. $^{-1}$ & 308.4 ng..$^{-1}$ & 130.3 ng..$^{-1}$ & $12.3 \mathrm{ng.}^{-1}$ \\
\hline Creatinine & $2.72 \mathrm{mg} \cdot \mathrm{dl}^{-1}$ & $1.41 \mathrm{mg} \cdot \mathrm{dl}^{-1}$ & $0.65 \mathrm{mg} \cdot \mathrm{dl}^{-1}$ & $0.61 \mathrm{mg} \cdot \mathrm{dl}^{-1}$ \\
\hline Bilirubin & $2.9 \mathrm{mg} \cdot \mathrm{dl}^{-1}$ & $0.8 \mathrm{mg} \cdot \mathrm{dl}^{-1}$ & $0.7 \mathrm{mg} \cdot \mathrm{dl}^{-1}$ & $0.5 \mathrm{mg} \cdot \mathrm{dl}^{-1}$ \\
\hline
\end{tabular}

ICU, intensive care unit; CRP, C-reactive protein; LDH, lactate dehydrogenase; CK, creatine kinase.

\section{Diagnostic assessment}

A nasopharyngeal swab and reverse transcriptase-polymerase chain reaction (RT-PCR) for COVID-19 was negative, but COVID-19 serology was IgM negative and IgG positive. Microbiological screening (urine, blood, sputum and stool culture), serological tests (virus, parasites, fungi and bacteria), and a Mantoux test were carried out. His thoracoabdominal CT scan showed multiple para-aortic and peri-pancreatic lymphadenopathy (compatible with lymphoproliferative syndrome as the most likely diagnosis) and acute respiratory distress syndrome (ARDS). There was no sign of pulmonary thromboembolism, but there were signs of pulmonary hypertension. He was admitted to the ICU and treated with broad spectrum antibiotics (imipenem $1 \mathrm{~g} / 8 \mathrm{~h}$, linezolid $600 \mathrm{mg} / 12 \mathrm{~h}$ ) and a low dose of norepinephrine $(0.05 \mathrm{mcg} / \mathrm{kg} / \mathrm{min})$.

An investigation of lymphoproliferative syndrome considering the possibility of hemophagocytic syndrome secondary to COVID-19 was carried out, including autoimmune tests. Protein electrophoresis showed an inflammatory pattern and a direct Coombs test was negative. A bone marrow biopsy showed reactive cells, without atypical cellularity, discarding lymphoproliferative or hemophagocytic syndrome. Tests for autoimmune diseases revealed a low level of C3 and positivity for lupus anticoagulant. The rest of the antibody tests were negative.

Microbiological screening, serological test and Mantoux were all negative, supporting the theory of an exaggerated systemic inflammatory response due to COVID-19. Septic shock was ruled out, so we decided to withdraw antibiotics. Only a rectal swab was positive for COVID-19.

During his time in hospital, the patient presented with acute confusion and agitation. He had no meningeal signs on examination. Cranial CT scan was normal and symptoms remitted within 24 hours.

An electrocardiograph showed atrial fibrillation and diffuse T wave inversion. Transthoracic echocardiography (TTE) was performed regularly, due to elevated cardiac enzymes. The first TTE was normal, but on the third day of admission demonstrated moderate biventricular dysfunction that progressed to severe in the following 24 hours, and atrial fibrillation. The evolution of echocardiographic parameters during admission to the ICU is shown in Table 1.

\section{Therapeutic intervention}

From the beginning our patient was treated with a nasal cannula at 3 liters/minute for five days and a venturi mask at $40 \%$ $\mathrm{FiO}_{2}$ for four days. Also, broad spectrum antibiotics (at the beginning, $1 \mathrm{~g} / 8 \mathrm{~h}$ imipenem and $600 \mathrm{mg} / 12 \mathrm{~h}$ linezolid for six days, and on the third day of admission, $500 \mathrm{mg} / 24 \mathrm{~h}$ daptomycin and $200 \mathrm{mg} / 24 \mathrm{~h}$ fluconazole were added to the regimen) and a low dose of norepinephrine $(0.05 \mathrm{mcg} / \mathrm{kg} / \mathrm{min})$ were administered. 
Table 2. Echocardiographic parameters.

\begin{tabular}{|l|l|l|l|l|l|l|}
\hline & Day 3 & Day 4 & $\begin{array}{l}\text { 4 hours after } \\
\text { levosimendan }\end{array}$ & $\begin{array}{l}\text { 12 hours after } \\
\text { levosimendan }\end{array}$ & $\begin{array}{l}\text { 24 hours after } \\
\text { levosimendan }\end{array}$ & $\begin{array}{l}\text { ICU } \\
\text { discharge }\end{array}$ \\
\hline LVEF & $46 \%$ & $32 \%$ & $40 \%$ & $45 \%$ & $50 \%$ & $65 \%$ \\
\hline LVIDD & $59 \mathrm{~mm}$ & $56 \mathrm{~mm}$ & Normal & Normal & $53 \mathrm{~mm}$ & $53 \mathrm{~mm}$ \\
\hline SPAP & $55-60 \mathrm{mmHg}$ & $45 \mathrm{mmHg}$ & $40 \mathrm{mmHg}$ & $40 \mathrm{mmHg}$ & $35 \mathrm{mmHg}$ & $35 \mathrm{mmHg}$ \\
\hline SWave & $15 \mathrm{~cm} / \mathrm{seg}$ & $8 \mathrm{~cm} / \mathrm{seg}$ & $12 \mathrm{~cm} / \mathrm{seg}$ & $15 \mathrm{~cm} / \mathrm{seg}$ & $15 \mathrm{~cm} / \mathrm{seg}$ & $15 \mathrm{~cm} / \mathrm{seg}$ \\
\hline TAPSE & $25 \mathrm{~mm}$ & $11 \mathrm{~mm}$ & $17 \mathrm{~mm}$ & $23 \mathrm{~mm}$ & $23 \mathrm{~mm}$ & $17 \mathrm{~mm}$ \\
\hline
\end{tabular}

LVEF, left ventricular ejection fraction; LVIDD, left ventricular internal diameter in diastole; SPAP, pulmonary arterial systolic pressure; $S$ wave; systolic wave; TAPSE, tricuspid annular plane systolic excursion; ICU, intensive care unit.

When the possibility of a septic shock was ruled out, antibiotics were withdrawn and $8 \mathrm{mg} / 24$ hours dexamethasone was started to try to contain the cytokine storm due to COVID-19. The dose was increased to $12 \mathrm{mg}$ when he suffered with confusion, agitation and heart failure. The patient was treated with adrenalin up to $0.1 \mathrm{mcg} / \mathrm{kg} / \mathrm{min}, 12.5 \mathrm{mg} / 24 \mathrm{hours}$ levosimendan and $20 \mathrm{mg} / 8-12$ hours furosemide for eight days. A bolus of $150 \mathrm{mg}$ amiodaron followed by an infusion of $600 \mathrm{mg}$ in 24 hours was administered when atrial fibrillation was targeted. He was given enoxaparin $60 \mathrm{mg} / 24 \mathrm{hours}$ during the first days and then it was increased to $60 \mathrm{mg} / 12$ hours.

A new TTE that was performed four hours after levosimendan was initiated showed a moderate improvement in left ventricular function and a slight improvement in right ventricular function. In 12 hours, the cardiac function returned to normal and sinus rhythm was recovered (Table 2).

\section{Outcomes}

Hemodynamic support therapy was withdrawn, and oxygen therapy, furosemide and dexamethasone were progressively reduced. He didn't have any adverse events with the medication; it was well tolerated.

In a few days, the clinical picture resolved and the patient was discharged to the Internal Medicine ward. The evolution of his condition was very favorable. He was afebrile, hemodynamically stable, with good food tolerance and without other clinical symptoms. Microbiological screening was repeated by Internal Medicine and a stool culture was positive for group B Salmonella species. The patient had no symptoms, but ciprofloxacin was administered for seven days and then he was discharged hemodynamically stable, eupneic and with oxygen saturation of $99 \%$ with oxygen supply of $0.28 \%$. Two weeks later he left the hospital.

A timeline with information from the current episode of care is shown in Table 3.

CT, computed tomography; RT-PCR, reverse transcriptase polymerase chain reaction; ICU, Intensive Care Unit.

\section{Discussion}

The Systemic inflammatory response syndrome (SIRS) may be caused by sepsis of bacterial origin, but sometimes it is difficult to substantiate and the differential diagnosis from non-infectious conditions is frequently a challenge. Definitive diagnosis requires isolation of a microorganism, but occasionally this is not possible ${ }^{9}$. On the other hand, the ability of some viruses to trigger a secondary autoimmune condition is well known. As we said before, on many occasions it is difficult to find out what has been the true trigger of the SIRS. During the COVID-19 pandemic, cases of cardiac involvement have been described ${ }^{10-12}$ and in many cases autoimmune diseases secondary to infection have been triggered. Elevated levels of IL-6 have been detected in these patients, but we are unable to determine them in our hospital $^{13,14}$. The diagnosis of the disease can be complicated, and many times it is not possible to have absolute certainty, although due to possible complications, in cases of high suspicion, it is still necessary to treat.

In this case, cardiac failure especially contributed to the severity of the patient's condition. Myocarditis is an inflammatory disease of the heart muscle caused by viruses mainly, although bacteria, toxic drugs and autoimmune diseases can produce it too. The exacerbation of the inflammatory response along with the cytokine storm and its associated cardiodepressor and prothrombotic effects could be the cause of alterations in the coronary circulation (microcirculation and vasospasm), myocardial dysfunction, and increased oxygen consumption ${ }^{15}$. Cardiac magnetic resonance imaging is useful for diagnosis but only endomyocardial biopsy can establish the etiological diagnosis ${ }^{16}$. We did not perform an endomyocardial biopsy due to coagulopathy and the pandemic situation. 
Table 3. Timeline with information from the current episode of care.

\begin{tabular}{|c|c|}
\hline \multirow[t]{3}{*}{ Initial patient assessment } & $\begin{array}{l}\text { - A 16-year-old Spanish adolescent, Caucasian, no allergies, extrinsic } \\
\text { asthma treated with corticosteroids and aerosols occasionally. } \\
\text { - No relevant past interventions and no medical, family or psychosocial } \\
\text { history (including genetic) of interest. }\end{array}$ \\
\hline & $\begin{array}{l}\text { - Blood pressure } 70 / 30 \mathrm{mmHg} \text {, heart rate } 110 \mathrm{bpm} \text {, respiratory rate } 18 \mathrm{bpm} \text {, } \\
\text { axillary temperature } 38.5^{\circ} \mathrm{C} \text {. } \\
\text { - Lung auscultation: bibasilar crackles. } \\
\text { - Heart auscultation without murmurs. } \\
\text { - Hepatosplenomegaly, oliguria, no edemas, no cutaneous rash and no } \\
\text { arthritis. } \\
\text { - Diuresis } 170 \mathrm{ml} \text { in } 12 \text { hours. }\end{array}$ \\
\hline & $\begin{array}{l}\text { - General discomfort, asthenia and fever }\left(38^{\circ} \mathrm{C}\right) \text { for three days. } \\
\text { - He was treated with paracetamol and azithromycin at home. } \\
\text { - Six days after, he came to the emergency department with persistence of } \\
\text { symptoms, shortness of breath, arthromyalgia and diarrhea. }\end{array}$ \\
\hline \multirow[t]{2}{*}{$\begin{array}{l}\text { Diagnostic evaluation and } \\
\text { therapeutic interventions }\end{array}$} & $\begin{array}{l}\text { - Nasopharyngeal swab RT-PCR and serology of COVID-19. } \\
\text { - Blood test, protein electrophoresis. } \\
\text { - Thoracoabdominal CT scan. } \\
\text { - Microbiological screening and serological test. } \\
\text { - Bone marrow biopsy. } \\
\text { - Autoimmune test. } \\
\text { - Cranial CT scan. } \\
\text { - Electrocardiograph, transthoracic echocardiography. }\end{array}$ \\
\hline & $\begin{array}{l}\text { - Paracetamol } 1 \mathrm{~g} / 8 \mathrm{~h} \text { and azithromycin } 500 \mathrm{mg} / 24 \mathrm{~h} \text { for three days. } \\
\text { - Broad spectrum antibiotics (imipenem } 1 \mathrm{~g} / 8 \mathrm{~h} \text {, linezolid } 600 \mathrm{mg} / 12 \mathrm{~h} \text { for } \\
\text { six days). Daptomycin } 500 \mathrm{mg} / 24 \mathrm{~h} \text { and fluconazole } 200 \mathrm{mg} / 24 \mathrm{~h} \text { were } \\
\text { added on the third day of admission. } \\
\text { - Nasal cannula } 3 \text { liters } / \mathrm{minute} \text { for five days and then venturi mask at } 40 \% \\
\text { for four days. } \\
\text { - Norepinephrine } 0.05 \mu \mathrm{cg} / \mathrm{kg} / \mathrm{min} \text { for four days. } \\
\text { - Dexamethasone } 8 \mathrm{mg} / 24 \mathrm{~h} \text { for three days and later } 12 \mathrm{mg} / 24 \mathrm{~h} \text { for } \\
\text { four days. } \\
\text { - Enoxaparin } 60 \mathrm{mg} / 24 \mathrm{~h} \text { for three days and then } 60 \mathrm{mg} / 12 \mathrm{~h} \text { until discharge. } \\
\text { - Adrenalin } 0.1 \mu \mathrm{cg} / \mathrm{kg} / \mathrm{min} \text { for two days. } \\
\text { - Levosimendan } 12.5 \mathrm{mg} \text { in } 24 \text { hours. } \\
\text { - Furosemide } 20 \mathrm{mg} / 8-12 \mathrm{~h} \text { for eight days. } \\
\text { - Bolus of amiodaron } 150 \mathrm{mg} \text {, followed of an infusion of } 600 \mathrm{mg} \text { in } 24 \mathrm{~h} \text {. }\end{array}$ \\
\hline \multirow[t]{2}{*}{ Outcomes and follow-up } & $\begin{array}{l}\text { - After a good recovery in ICU, the patient was discharged to the Internal } \\
\text { Medicine ward. } \\
\text { - He was afebrile, hemodynamically stable, without antibiotics and } \\
\text { decreasing dosage of corticosteroids. } \\
\text { - A new stool culture was positive for group B Salmonella species. } \\
\text { - He had no symptoms, but ciprofloxacin was administered for seven days } \\
\text { and then he was discharged. }\end{array}$ \\
\hline & $\begin{array}{l}\text { - In a follow-up visit to the Internal Medicine clinic he remained } \\
\text { asymptomatic and without sequelae. } \\
\text { - Cardiac magnetic resonance imaging was performed, which was normal. }\end{array}$ \\
\hline
\end{tabular}

The patient was treated with adrenaline, diuretics, and levosimendan. He was also receiving anti-inflammatory treatment with dexamethasone, for suspicion of a possible immunological disease secondary to COVID-19 ${ }^{17}$. heart function recovered in a couple of days. The benefits of levosimendan in infectious myocarditis have been endorsed by different studies. It has been shown to be superior over dobutamine in terms of mortality in patients with heart failure ${ }^{18,19}$. It is a novel drug to treat myocardial dysfunction due to sepsis ${ }^{20}$, myocardial infarction with left ventricular failure ${ }^{21}$ or cardiac decompensation ${ }^{22}$. Its cardioprotective effects are because it causes coronary vasodilation, reduces preloading and postloading, and activates mitochondrial-K+ ATP channels. Its inotropic, coronary, antiplatelet, antiapoptotic, and antiinflammatory effects increases cardiac output and decreases the ventricular filling pressure, pulmonary and systemic vascular resistance ${ }^{23}$. This was the reason we decided to use levosimendan, after not getting a full response to adrenaline and the progression of the patient was satisfactory.

When he was discharged to the Internal Medicine ward, he continued to show favorable progress and clinical improvement. However, they repeated the stool culture again and it was positive for Salmonella species and treated 
with ciprofloxacin, although the patient remained asymptomatic. In subsequent check-ups the patient had no sequelae of the disease and cardiac magnetic resonance imaging was performed, which was normal. This makes us suspect that the Salmonella infection was probably acquired in hospital and it was not the cause of myocarditis, although we cannot completely rule it out.

\section{Data availability}

All data underlying the results are available as part of the article and no additional source data are required.

\section{Consent}

Written informed consent for publication of their clinical details was obtained from the patient.

\section{References}

1. Silva Júnior JVJ, Lopes TRR, de Oliveira PSB, et al.: Issues on Coronavirus Disease 2019 (COVID-19) Pathogenesis. Viral Immunol. 2020 Apr 27 [cited 2020 May 11] PubMed Abstract | Publisher Full Text

2. Channappanavar R, Perlman S: Pathogenic human coronavirus infections: causes and consequences of cytokine storm and immunopathology. Semin Immunopathol. Springer Verlag; 2017; Vol. 39, p. 529-39.

PubMed Abstract | Publisher Full Text | Free Full Text

3. Babapoor-Farrokhran S, Gill D, Walker J, et al.: Myocardial injury and COVID-19: Possible mechanisms. Life Sci. 2020 Jul [cited 2020 May 11]; 253: 117723.

Reference Source. | PubMed Abstract | Publisher Full Text | Free Full Text

4. Chow J, Alhussaini A, Calvillo-Argüelles O, et al.: Cardiovascular Collapse in COVID-19 Infection: The Role of Veno-Arterial Extracorporeal Membrane Oxygenation (VA-ECMO). CJC Open. $2020 \mathrm{Apr}$

PubMed Abstract | Publisher Full Text | Free Full Text

5. Guerrero-OrriachJL, Ariza-Villanueva D, Florez-Vela A, et al.: Cardiac, renal, and neurological benefits of preoperative levosimendan administration in patients with right ventricular dysfunction and pulmonary hypertension undergoing cardiac surgery: Evaluation with two biomarkers neutrophil gelatinaseassociated lipocalin and neuronal enolase. Ther Clin Risk Manag. 2016 Apr 21; 12: 623-630.

PubMed Abstract | Publisher Full Text | Free Full Text

6. Chen $\mathrm{QH}$, Zheng RQ, Lin $\mathrm{H}$, et al.: Effect of levosimendan on prognosis in adult patients undergoing cardiac surgery: A meta-analysis of randomized controlled trials. Crit Care. 2017 Oct; 17; 21(1)

PubMed Abstract | Publisher Full Text | Free Full Text

7. Mattos-Silva P, Felix NS, Silva PL, et al.: Pros and cons of corticosteroid therapy for COVID-19 patients. Respir Physiol Neurobiol. 2020 Sep 1; 280: 103492.

PubMed Abstract | Publisher Full Text | Free Full Text

8. Pascarella G, Strumia A, Piliego C, et al.: COVID-19 diagnosis and management: a comprehensive review. J Intern Med. Blackwell Publishing Ltd; 2020; Vol. 288: p. 192-206.

PubMed Abstract | Publisher Full Text | Free Full Text

9. Procalcitonin as a diagnostic and prognostic marker for sepsis caused by intestinal infection: a case report. 2020 Sep 19.

PubMed Abstract

10. Irabien-Ortiz Á, Carreras-Mora J, Sionis A, et al.: Fulminant myocarditis due to COVID-19. Rev Esp Cardiol. 2020 Jun 1; 73(6): 503-504.

PubMed Abstract | Publisher Full Text | Free Full Text

11. Zeng JH, Liu YX, Yuan J, et al.: First case of COVID-19 complicated with fulminant myocarditis: a case report and insights. Infection. 2020.

PubMed Abstract | Publisher Full Text | Free Full Text

12. Chen C, Zhou Y, Wang DW: SARS-CoV-2: a potential novel etiology of fulminant myocarditis. Herz. Springer Medizin; 2020;
Vol. 45: p. 230-232.

PubMed Abstract | Publisher Full Text | Free Full Text

13. McGonagle D, Sharif K, O'Regan A, et al.: The Role of Cytokines including Interleukin-6 in COVID-19 induced Pneumonia and Macrophage Activation Syndrome-Like Disease. Autoimmunity Rev. Elsevier B.V.; 2020; Vol. 19: p. 102537.

PubMed Abstract | Publisher Full Text | Free Full Text

14. Wang W, Ye L, Ye L, et al.: Up-regulation of IL- 6 and TNF- $\alpha$ induced by SARS-coronavirus spike protein in murine macrophages via NF-кB pathway. Virus Res. 2007 Sep; 128(1-2): 1-8. PubMed Abstract | Publisher Full Text | Free Full Text

15. Dominguez F, Kühl U, Pieske B, et al.: Update on Myocarditis and Inflammatory Cardiomyopathy: Reemergence of Endomyocardial Biopsy. Rev Esp Cardiol (Engl Ed). 2016 Feb; 69(2): 178-187.

PubMed Abstract | Free Full Text

16. Friedrich MG, Sechtem U, Schulz-Menger J, et al.: Cardiovascular Magnetic Resonance in Myocarditis: A JACC White Paper. J Am Coll Cardiol. 2009; 53: 1475-1487. PubMed Abstract | Publisher Full Text | Free Full Text

17. Chen RC, Tang XP, Tan SY, et al.: Treatment of severe acute respiratory syndrome with glucosteroids: The Guangzhou experience. Chest. 2006; 129(6): 1441-1452. PubMed Abstract | Publisher Full Text | Free Full Text

18. Cleland JGF, Ghosh J, Freemantle N, et al.: Clinical trials update and cumulative meta-analyses from the American College of Cardiology: WATCH, SCD-HeFT, DINAMIT, CASINO, INSPIRE, STRATUS-US, RIO-LIPIDS and cardiac resynchronisation therapy in heart failure. Eur J Heart Fail. 2004; 6: 501-508. PubMed Abstract | Publisher Full Text

19. Follath $\mathrm{F}$, Cleland JGF, Just $\mathrm{H}$, et al.: Efficacy and safety of intravenous levosimendan compared with dobutamine in severe low-output heart failure (the LIDO study): A randomised double-blind trial. Lancet. 2002 Jul 20; 360(9328): 196-202. PubMed Abstract | Publisher Full Text

20. Gong B, Li Z, Yat Wong PC: Levosimendan Treatment for Heart Failure: A Systematic Review and Meta-Analysis. J Cardiothorac Vasc Anesth. 2015 Dec 1; 29(6): 1415-1425. PubMed Abstract | Publisher Full Text

21. Moiseyev VS, Põder P, Andrejevs N, et al.: Safety and efficacy of a novel calcium sensitizer, levosimendan, in patients with left ventricular failure due to an acute myocardial infarction: $A$ randomized, placebo-controlled, double-blind study (RUSSLAN). Eur Heart J. 2002 Sep; 23(18): 1422-1432. PubMed Abstract | Free Full Text

22. Packer $\mathrm{M}$, Colucci $\mathrm{W}$, Fisher $\mathrm{L}$, et al.: Effect of levosimendan on the short-term clinical course of patients with acutely decompensated heart failure. JACC Hear Fail. 2013 Apr; 1(2): 103-111. PubMed Abstract | Publisher Full Text

23. G L, R A, I P, et al.: Preoperative Levosimendan. A New Way for Organoprotection. Curr Pharm Des. 2014 Sep 15; 20(34): 5476-5483.

PubMed Abstract | Publisher Full Text 


\section{Open Peer Review}

\section{Current Peer Review Status: ? ?}

\section{Version 1}

Reviewer Report 03 November 2022

https://doi.org/10.5256/f1000research.53866.r154671

(C) 2022 Jakovac $\mathbf{H}$. This is an open access peer review report distributed under the terms of the Creative Commons Attribution License, which permits unrestricted use, distribution, and reproduction in any medium, provided the original work is properly cited.

\section{Hrvoje Jakovac \\ University of Rijeka, Rijeka, Croatia}

The authors bring an interesting case of a 16-year-old boy with severe COVID-19. Although the authors claim the cytokine storm was an underlying mechanism, there is no clear evidence that this was the scenario in described patients (the authors did not measure plasma cytokine concentration).

The following sentence in the Introduction section is not clear: "The myocardial depressant effect of cytokines, an oxygen deficit generated by a prothrombotic state and coronary vasospasms could cause cardiac injury and dysfunction in other organs". Can SARS-CoV-2 directly infect the cardiac conduction system and cause arrhythmias? (See and refer to:

https://doi.org/10.3390/tropicalmed703004311)

The patient's asthma had been treated with corticosteroids and aerosols occasionally. Please provide the treatment regimen and doses in more detail. Could asthma (and corticosteroids) have been a risk factor for the patient described? Please discuss.

Was SpO2 measured by pulse oximetry immediately at admission?

Please provide data on the patient's state of consciousness at admission.

Were there any physical signs of dehydration in the patient upon admission (skin turgor, dry mucous membranes)?

Please describe the patient's diarrhea (duration, stool frequency, number of stools).

Please show normal laboratory values in parentheses for each parameter.

Please provide data on the kit/device used for RT-PCR.

The lack of nasopharyngeal RT-PCR positivity with rectal swabs being positive is the most intriguing detail, but the authors did not discuss it. Please include it in the discussion. What are the potential causes of such findings? Is there any role of ACE2 distribution (see and refer to: https://doi.org/10.1152/ajplung.00119.2020²) 
The discussion section should be more comprehensive, including consideration of the mechanisms of cardiac affection and arrhythmias described (see above).

\section{References}

1. Jakovac H, Ferenčić A, Stemberger C, Mohar Vitezić B, et al.: Detection of SARS-CoV-2 Antigens in the AV-Node of a Cardiac Conduction System-A Case Report. Tropical Medicine and Infectious Disease. 2022; 7 (3). Publisher Full Text

2. Jakovac H: COVID-19: is the ACE2 just a foe?. American Journal of Physiology-Lung Cellular and Molecular Physiology. 2020; 318 (5): L1025-L1026 Publisher Full Text

Is the background of the case's history and progression described in sufficient detail? Yes

Are enough details provided of any physical examination and diagnostic tests, treatment given and outcomes?

Partly

Is sufficient discussion included of the importance of the findings and their relevance to future understanding of disease processes, diagnosis or treatment? Partly

Is the case presented with sufficient detail to be useful for other practitioners? Yes

Competing Interests: No competing interests were disclosed.

Reviewer Expertise: COVID-19, heat shock proteins, oncogenesis, autoimmunity, neuroscience

I confirm that I have read this submission and believe that I have an appropriate level of expertise to confirm that it is of an acceptable scientific standard, however I have significant reservations, as outlined above.

Reviewer Report 09 December 2021

https://doi.org/10.5256/f1000research.53866.r97530

(C) 2021 Bonazzetti C. This is an open access peer review report distributed under the terms of the Creative Commons Attribution License, which permits unrestricted use, distribution, and reproduction in any medium, provided the original work is properly cited.

\section{Cecilia Bonazzetti}

Department of Infectious Diseases, ASST Fatebenefratelli-Sacco, Luigi Sacco University Hospital, Milan, Italy

This case report is well described, at times almost redundant. The description of the clinical case is interesting and complete in all information. However, the discussion should be revised because it 
lacks a very important etiological entity talking about this topic which is the MIS-C and the most important works regarding this topic are not even mentioned: Feldstein et al., $2020^{1}$, jiang et al., $2020^{2}$.

\section{References}

1. Feldstein L, Rose E, Horwitz S, Collins J, et al.: Multisystem Inflammatory Syndrome in U.S. Children and Adolescents. New England Journal of Medicine. 2020; 383 (4): 334-346 Publisher Full Text

2. Jiang L, Tang K, Levin M, Irfan O, et al.: COVID-19 and multisystem inflammatory syndrome in children and adolescents. The Lancet Infectious Diseases. 2020; 20 (11): e276-e288 Publisher Full Text

Is the background of the case's history and progression described in sufficient detail? Yes

Are enough details provided of any physical examination and diagnostic tests, treatment given and outcomes?

Yes

Is sufficient discussion included of the importance of the findings and their relevance to future understanding of disease processes, diagnosis or treatment?

No

Is the case presented with sufficient detail to be useful for other practitioners?

Yes

Competing Interests: No competing interests were disclosed.

Reviewer Expertise: Infectious Disease

I confirm that I have read this submission and believe that I have an appropriate level of expertise to confirm that it is of an acceptable scientific standard, however I have significant reservations, as outlined above. 
The benefits of publishing with F1000Research:

- Your article is published within days, with no editorial bias

- You can publish traditional articles, null/negative results, case reports, data notes and more

- The peer review process is transparent and collaborative

- Your article is indexed in PubMed after passing peer review

- Dedicated customer support at every stage

For pre-submission enquiries, contact research@f1000.com 